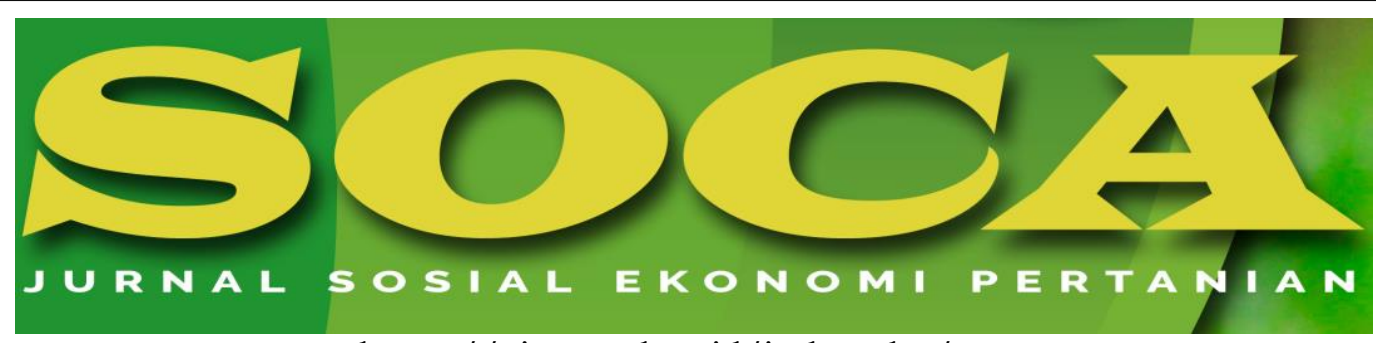

https://ojs.unud.ac.id/index.php/soca

\title{
Forecasting of Paddy Grain and Rice's Price: An ARIMA (Autoregressive Integrated Moving Average) Model Application
}

Fitri Ramadhani, Ketut Sukiyono and Melli Suryanty

Bengkulu University, Bengkulu City, Bengkulu Province

Email: ksukiyono@unib.ac.id

Handphone: 0813-6799-9597

Submitted: 27 January 2020; Revised: 24 February 2020; Accepted: 13 March 2020

\section{Keywords: \\ ARIMA; rice; paddy grain; forecasting.}

\begin{abstract}
Abstrak
A decision making for a long-term paddy grain and rice price guidelines need a future price prediction and a forecasting model that made based on time progression. The most popular model used is ARIMA. The common problem in forecasting the paddy grain and rice in Indonesia using this model was choosing the best model which fit all type of forecasting. This study aimed to determine the most appropriate ARIMA Model and forecast paddy grain and rice's price on the farmer level, wholesale level, and international level. The prediction began after the stationary test and the best model selection conducted. The ARIMA model used was chosen by the lowest AIC and SC accuracy value. ARIMA Model used in this study were grain price on the farmer level $(1,1,2)$, grain price on the milling level $(1,1,2)$, rice price on the wholesale level $(1,1,3)$, and rice price on the international level $(3,1,7)$. The rice price prediction in the next sixth months on the farmer level was IDR 5,905.15/ kg and the actual price was IDR 5,524.89/ kg, on the milling level was IDR $6,014.35 / \mathrm{kg}$ and the actual price was IDR 5,641/ $\mathrm{kg}$, on the wholesale level was IDR 12,163.92/ kg and the actual price IDR $12,115 / \mathrm{kg}$, while the on the international level was US\$ 462,065/Ton and the actual price was US\$ 408/Ton. This study concluded that the price list at a different level of the market was requiring a different model of ARIMA.
\end{abstract}

How to Cite (APA 6 ${ }^{\text {th }}$ Style):

Ramadhani, F., Sukiyono, K., \& Suryanty, M. (2020). Forecasting of Paddy Grain and

Rice's Price: An ARIMA (Autoregressive Integrated Moving Average) Model Application. SOCA: Jurnal Sosial Ekonomi Pertanian, 14(2), 224-239. https://doi.org/https://doi.org/10.24843/SOCA.2020.v14.i02.p04 


\section{INTRODUCTION}

Rice is a staple food in Indonesia which is produced from paddy plant. Rice could be categorized as a strategic commodity politically. Rice plays a strategic role in strengthening the food, economic, and political security/stability in a country. Consequently, a stable rice stock, price, and distribution are necessary for Indonesia. Those facts indicated that rice contributed a major role in Indonesia, therefore rice price stabilizing is required to be conducted by the government.

Forecasting technique is a solution offered to support the decision making in stabilizing the rice price (Mariska, 2016). A decision making using a forecasting technique required an estimation that could be analyzed through a time series analysis. Wei (2006) stated that based on the number of the observed variables, the time series model could be divided into two models: univariate time series model that only uses one variable and multivariate time series that use more than one variable. ARIMA (Autoregressive Integrated Moving Average) Model is a univariate time series model use to forecast the price.

The main requirement on the AR, MA, and ARMA model is stationary on the time series data used. The time-series data would be reached the stationary state if it shows a consistent pattern in a period to another period in its mean or variance. If the time series was not in a stationary state, a differencing process is needed. This process is done by finding the difference between periods. If AR, MA, or ARMA data reach the stationary state using this process, this model shifted into Autoregressive Integrated Moving Average (ARIMA) model. A further identification process also has to be conducted to found the best ARIMA model (Juanda, Bambang, and Junaidi, 2012). Makridakis et al., (1999) stated that Box-Jenkins method or Autoregressive Integrated Moving Average (ARIMA) using the order of (p, d, q), p represents the degree of Autoregressive (AR) degree, $d$ represents the degree of Integration (I) and $q$ represents the degree of Moving Average (MA).

Some studies also found that the ARIMA model is the best model used in forecasting. A study conducted by Novanda, et al (2018) on the coffee commodity, Sukiyono and Rosdiana (2018) on rice price on the wholesale level, Putri and Wiwik (2018) on the chili price, and Sukiyono, et al (2018) on cacao commodity showed that ARIMA model was quite accurate in forecasting data. A common problem found in using this model was choosing the best model to forecast the price as stated by Salwa, et al. (2018) on bitcoin price, Hadiansyah (2017) on chili price, Dağistan, Kız1ltuğ, \& Çelik (2017) for potato commodity in Turkei, and Sugiarto et al. (2017) for palm oil commodity.

Based on these explanations, the best ARIMA model in forecasting the paddy grain and rice price in Indonesia for supporting the decision making of the stable rice price is required to be conducted. The best ARIMA model was important in predicting the agricultural commodity price, strategic plan, improving the profit, and decreasing the cost needed. Using the ARIMA model to forecast the paddy grain and rice price in Indonesia was required an appropriate order determination from this model. This study aimed to determine the best ARIMA model that was made base on the value of $\mathrm{p}, \mathrm{d}, \mathrm{q}$ and the lowest value of the forecasting accuracy. 


\section{RESEARCH METHODS}

All data engaged in this study were national and international ranged data. Indonesia's agricultural data was chosen to be investigated due to some considerations: (1) Indonesia is an agrarian country and depends on its rice commodity as their staple food and (2) Indonesia contributed dominantly on the production of rice on the international level.

Secondary data type in the form of monthly time series data ranged in 20082018 was analyzed in this study. The data used paddy grain's price on the farmer level, paddy grain's price on the milling level, rice price on the wholesale level, and rice price on the international level. Indonesia National Institute of Statistical Data (www.bps.go.id) and Mundi index (www.indexmundi.com) provided all the data employed in this study.

The most important thing in managing a time series data is the data stationary. The data was stated in a stationary state if they show a consistent pattern in its median or variance. There are two types of data stationary: stationary state to data mean and stationary state to data variance. If the stationary state to data means can't be achieved, a differencing process was required to be conducted on that data. Differencing is a process in finding the data difference in one period with another period in consecutive order. The data produced by the differencing process was called the first differentiation level of data. If the data couldn't reach a stationary state on the first differentiation, another differentiation process was needed to be conducted until the data reach the stationary state. At the end of the differentiation technique, we would obtain an order (d) from the order $(p, d, q)$ which named as an ARIMA model.

\section{RESULT AND DISCUSSION}

\section{The Plot of Paddy Grain and Rice Price Data in Indonesia}

Time series data ranged from January 2008 until November 2018 was used to forecast the paddy grain and rice price in Indonesia. The data was provided by the National Institute of Statistical Data and processed with the E-views.

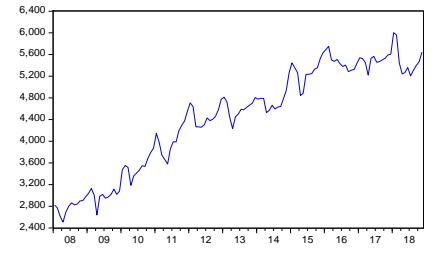

(a) Paddy Grain on Farmer Level

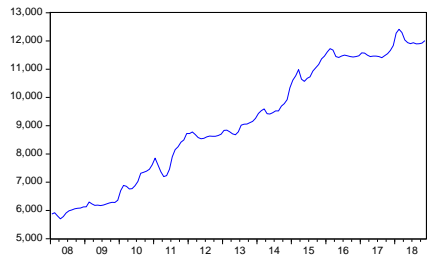

(c) Rice on Wholesale Level

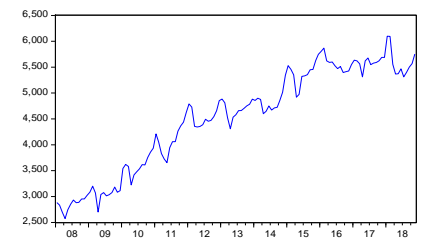

(b) Paddy Grain on Milling Level

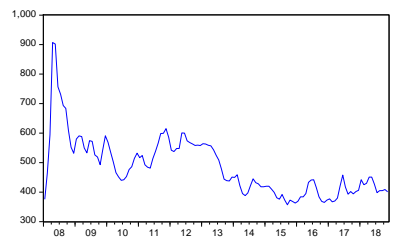

(d) Rice on International Level

Figure 1. The Plot of Paddy Grain and Rice Price Data in Indonesia, 2008-2018 Source : National Institute of Statistical Data (2019) 
Based on Figure 1., the paddy grain price on farmer and milling level fluctuated. The price on the farmer level was ranged IDR $2,000-6,000 / \mathrm{kg}$ in each month. The price reached IDR $6,000 / \mathrm{kg}$ in January 2018. It showed that the price increased from the previous month. However, the price decreased in the following months. At the milling level, the price ranged IDR $2,000-6,000 / \mathrm{kg}$ on each month. The price also reached IDR $6,000 / \mathrm{kg}$ on January and February 2018 and then decreased in the next months. Meanwhile, at the wholesale level, the rice price was also fluctuating and relatively increasing each month which ranged on IDR $5,000-12,000 / \mathrm{kg}$. The price was reached IDR $12.000 / \mathrm{kg}$ from January until April 2018, then keep decreased in the next months, and reached IDR 12,000/kg again in November 2018. Whereas, the international rice price was ranged US\$300-900/Metric ton during the observations. In May and June 2018 the prices increased sharply from US\$ 594 to US\$ 907 and US\$901, but decreased again to US\$ 757 and relatively decreasing in the following months.

\section{Data Stationary}

Juanda and Junaidi (2012) stated that time-series data was stated as a fixed or in the stationary state if the mean and variance constant in all periods. Differencing process is required to be conducted to obtain data in a stationary state.

\section{Data Stationary of the Paddy Grain in Farmer Level}

The paddy grain price data was not in a stationary state. Figure 2 shows the paddy grain price stationary test on the farmer level.

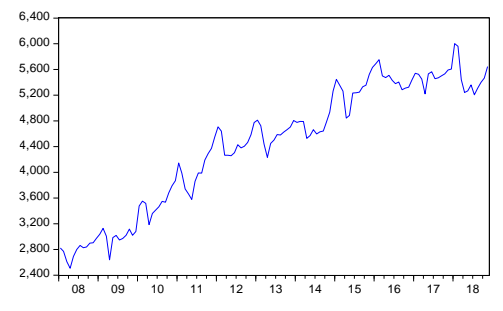

(a) Level

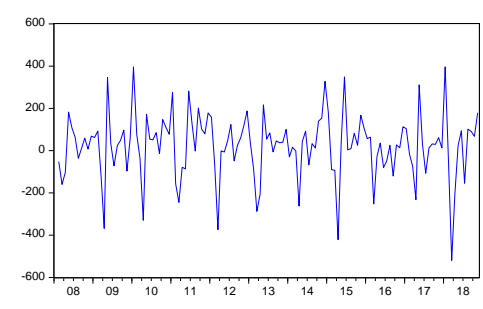

(b) Differentiation

Figure 2. Paddy Grain Stationary Test in the Farmer Level

Source : Primary Data (processed in E-views), 2019

The price data area on the graphic (a) was not in a stationary state, therefore a differencing process was conducted. The data stationary was counted by using the Augmented Dickey-Fuller (ADF) test. If $\mid$ ADF test statistics $|>|$ critical point $\mid>$ reached the critical point of $5 \%$, the data was reached in a stationary state. Based on the table, the statistical value of the ADF test, the ADF test statistical value $>$ from the critical point was $5 \%$ or $|-10.82172>-2.885863|$. This result indicated that the price was already in a stationary state.

Table 1. ADF Test on Paddy Grain Price in Farmer Level

\begin{tabular}{llcc}
\hline & t-Statistic & Prob. $^{*}$ \\
\hline Augmented Dickey-Fuller Test Statistic & -10.82172 & 0.0000 \\
\hline Test Critical Values: & 1\% level & -3.486064 & \\
& 5\% level & -2.885863 & \\
& $10 \%$ level & -2.579818 & \\
\hline
\end{tabular}

Source : Processed Primary Data (2019) 


\section{Data Stationary on the Paddy Grain Price on the Milling Level}

The paddy grain price data was not in a stationary state. Figure 3 shows the paddy grain price stationary test on the milling level.

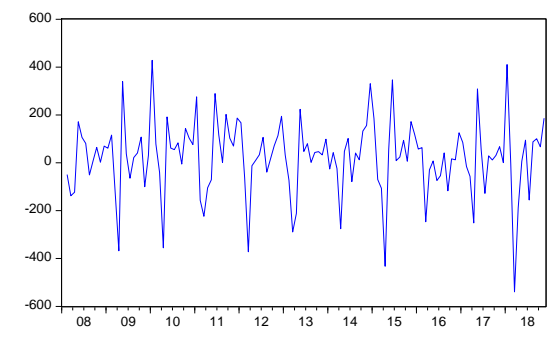

(a) Level

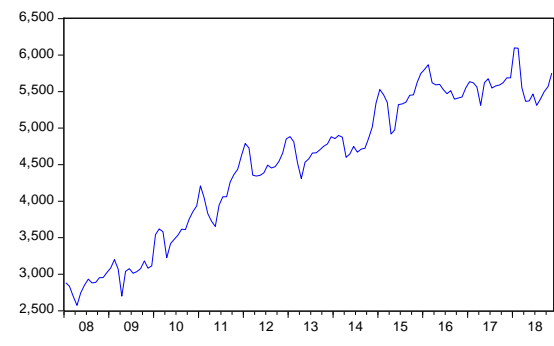

(b) Differentiation (1)

Figure 3. Paddy Grain Price Stationary Test on Milling Level Source : Primary Data (processed in E-views), 2019

The price data area on the graphic (a) was not in a stationary state, therefore a differencing process was conducted. The stationary state was already reached in graphic (b). The data stationary was counted by using the Augmented Dickey-Fuller $(\mathrm{ADF})$ test. If $\mid \mathrm{ADF}$ test statistics $|>|$ critical point $\mid>$ reached the critical point of $5 \%$, the data was reached in a stationary state. Table 2 . is showed the paddy grain price on the milling level.

Based on Table 2, the statistical value of the ADF test ADF $>$ from the critical point was $5 \%$ or $|-10.64446>-2.886074|$, this result indicated that the price was already in a stationary state.

Table 2. Paddy Grain Price ADF Test on Milling Level

\begin{tabular}{lccc}
\hline & & t-Statistic & Prob. $^{*}$ \\
\hline Augmented Dickey-Fuller Test Statistic & -10.644460 & 0.0000 \\
\hline Test Critical Values: & 1\% level & -3.486551 & \\
& 5\% level & -2.886074 & \\
& $10 \%$ level & -2.579931 & \\
\hline
\end{tabular}

Source : Primary Data (2019)

\section{Data Stationary on the Rice Price on the Wholesale Level}

The rice price data was not in a stationary state. Figure 4 shows the rice price stationary test on the wholesale level.

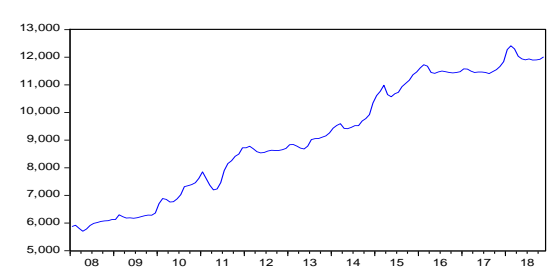

(a) Level

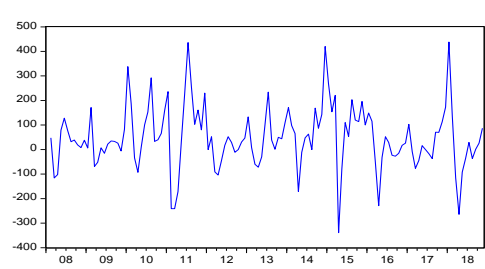

(b) Differentiation (1)

Figure 4. Rice Price Stationary Test on Wholesale Level Source : Primary Data (processed in E-views), 2019 
The price data area on the graphic (a) was not in a stationary state, therefore a differencing process was conducted. The stationary state was already reached in graphic (b). The data stationary was counted by using the Augmented Dickey-Fuller (ADF) test as shown in Table 3.

Table 3. ADF Test on the Rice Price in Wholesale Level

\begin{tabular}{lccc}
\hline & & t-Statistic & Prob. $^{*}$ \\
\hline Augmented Dickey-Fuller Test Statistic & -8.884748 & 0.0000 \\
\hline Test Critical Values: & 1\% level & -3.486064 & \\
& 5\% level & -2.885863 & \\
& $10 \%$ level & -2.579818 & \\
\hline
\end{tabular}

Source : Processed Primary Data (2019)

Based on the table, the statistical value of the ADF test ADF $>$ from the critical point was $5 \%$ or $|-8.884748>-2.885863|$, this result indicated that the price was already in a stationary state.

\section{Data Stationary on the Rice Price on the International Level}

The rice price data was not in a stationary state. Figure 5 . shows the rice price stationary test on the international level.

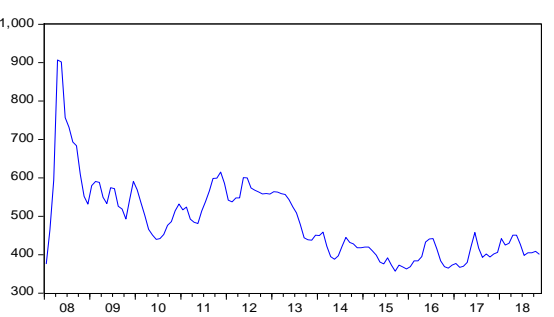

(a) Level

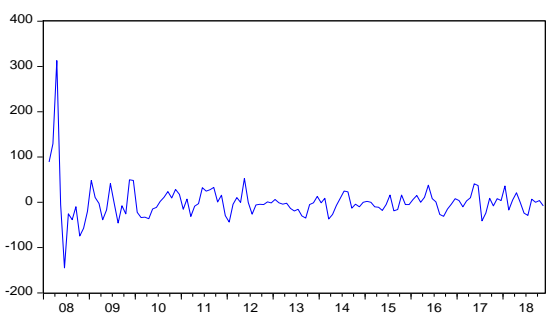

(b) Differentiation (1)

Figure 5. Rice Price Stationary Test on International Level Source : Primary Data (processed in E-views), 2019

The price data area on the graphic (a) was not in a stationary state, therefore a differencing process was conducted. The stationary state was already reached in graphic (b). The data stationary was counted by using the Augmented Dickey-Fuller (ADF) test as shown in Table 4.

Table 4. ADF Test on the Rice Price in International Level

\begin{tabular}{llll}
\hline & & t-Statistic & Prob. $^{*}$ \\
\hline Augmented Dickey-Fuller Statistical Test & -8.376158 & 0.0000 \\
\hline Critical Values Test: & 1\% level & -3.485586 & \\
& 5\% level & -2.885654 & \\
& 10\% level & -2.579708 & \\
\hline
\end{tabular}

Source : Primay Data (2019)

Based on Table 4, the statistical value of the ADF test $>$ than the $5 \%$ crisis point or $|-8.376158>-2.885654|$. This was indicated that the price was already balanced (stationary). 


\section{ARIMA (Autoregressive Integrated Moving Average)}

ARIMA model (p, d, q) was classified into three main components: AR (Autoregressive) with the order of (p), Integrated with an order of (d) or differencing, and MA (Moving Average) with the order of (q). After the data already at stationary state, the best model of ARIMA according to its lower AIC (Akaike Information Criterion) and SC (Schwarz Criterion) score could be determined.

\section{The Determination of ARIMA Model on the Paddy Grain Price}

The best ARIMA Model was ARIMA $(1,1,2)$ with the lowest accuracy value (AIC and SC) of 12.78823 and 12.87690. The ARIMA Model $(1,1,2)$ shown in Table 5.

Table 5. ARIMA based on the Estimation Result

\begin{tabular}{lclc}
\hline Orde & AIC & SC & ARIMA Model \\
\hline $1,1,1$ & 12,86090 & 12,92741 & \\
$1,1,2$ & 12,78823 & 12,87690 & \\
$1,1,3$ & 12,80233 & 12,91318 & \\
$1,1,4$ & 12,79639 & 12,92940 & \\
$1,1,5$ & 12,80350 & 12,95869 & $1,1,2$ \\
$2,1,1$ & 12,80237 & 12,89149 & \\
$2,1,2$ & 12,79963 & 12,91104 & \\
$2,1,3$ & 12,79575 & 12,92944 & \\
$3,1,1$ & 12,81713 & 12,92910 & \\
\hline
\end{tabular}

Source : Primary Data (2019)

Based on the National Institute of Statistical Data in 2019, the paddy grain price fluctuated each month but relatively increased each month. On the other hand, the production of the rice also fluctuated but relatively decreased in each year. The price fluctuation of an agricultural commodity is an important component in agribusiness. The change of the agricultural price could affect the supply and the farmer in the production of an agricultural commodity (Cetin and Esengun, (2013); Arisoy \& Bayramoglu, (2017)). On the other side, the production of the agricultural commodity was affected by various factors: climate, pest, and disease. Both factors highly contributed to the agricultural commodity supply (Sarkar, 1992; Caliskan et al., 2010 in Erdal, et al, 2017).

The Cobweb or spider web theory is a theory that described the price fluctuation. This theory explains the reason behind the periodical price fluctuation on a certain product. This defines the market cycle demand and supply, the number of the product produced must be selected before the price determined (Web Definition, 2014). The price fluctuation of an agricultural commodity could be explained in some methods: (1) fluctuation happened because the production of an agricultural product was affected by their growing state. This caused the lower price in a higher production and higher price in lower production ("King Law"), (2) It is a function of market price resulted from the previous product supply (Ezekiel, 2013).

The number of agricultural supply which would be cultivated was decided based on the price during the harvest period. Therefore, information about the food commodity price would obtain information about the number of agricultural products to be cultivated in each season (White dan Dawson, 2005). The farmer has formed the price expectation in one period ahead to increase the production and the 
benefit (Naimzada, 2016). The farmer decision in cultivated rice paddy was also affected by the rice price in the previous harvesting season, as stated by Ezekiel (1938) that the farmer usually has a naive expectation, their price prediction was the same as the previous price observed.

\section{The Determination of ARIMA Model on the Paddy Grain Price on Willing Level}

Based on Table 6 , the best ARIMA model is $(1,1,2)$ with the lowest accuracy value (AIC and SC) of 12,82560 and 12,91428 which shown in Table 6.

Table 6. ARIMA based on the Estimation Result

\begin{tabular}{cccc}
\hline Orde & AIC & SC & ARIMA Model \\
\hline $1,1,1$ & 12,89851 & 12,96501 & \\
$1,1,2$ & 12,82560 & 12,91428 & \\
$1,1,3$ & 12,83953 & 12,95038 & \\
$1,1,4$ & 12,83560 & 12,96862 & $1,1,2$ \\
$2,1,1$ & 12,84297 & 12,93210 & \\
$2,1,2$ & 12,83773 & 12,94914 & \\
$2,1,3$ & 12,83941 & 12,97309 & \\
$3,1,1$ & 12,85685 & 12,96883 & \\
\hline
\end{tabular}

Source : Primary Data (2019)

The producer and cost factors do not modify the agricultural commodity price. The producers must be accepted the price set by the market like the fact. This happened due to the price of the agricultural commodity price was not determined by the cost used to grow the agricultural product, but by the total of the supply and demand on that year. Moreover, a production of the agricultural product also couldn't be changed in a short amount of time (Sarkar, 1992; Erdal and Erdal, 2008; Mulazzani and Camanzi, 2011; Ceyhan et al., 2012; Bor et al., 2014, Arisoy \& Bayramoğlu, 2017). The paddy grain price on the milling level in Indonesia was set based on the paddy grain price set in the farmer and the producer level. Based on the National Institute of Statistical Data (2019), the paddy grain price fluctuated in each month during 2008-2018, but relatively increasing in the yearly period. The production of paddy grain by the producer also relatively decreasing.

The cobweb theory was also applicable in explaining the paddy grain price. The cobweb theory stated that the price dynamic on perishable goods required one unit of time to produce (Brock \& Hommes, 1997). This statement was related to the paddy grain processed that required proper storage to assure its quality fitted the consumer demand. The quality of the paddy grain would be created different prices in the market. This condition was affected by the price fluctuation in the market. This price would be used to determine the paddy grain price in the next following period.

The Determination of ARIMA Model on the Paddy Rice Price on Wholesale Level

Table 7 showed that the best ARIMA model is $(1,1,3)$ with the lowest accuracy value (AIC dan SC) of 12,21163 and 12,32247. 
Table 7. ARIMA based on the Estimation Result

\begin{tabular}{cccc}
\hline Orde & AIC & SC & ARIMA Model \\
\hline $1,1,1$ & 12,29804 & 12,36455 & \\
$1,1,2$ & 12,27989 & 12,36856 & \\
$1,1,3$ & 12,21163 & 12,32247 & \\
$1,1,4$ & 12,26886 & 12,40187 & $1,1,3$ \\
$2,1,1$ & 12,25960 & 12,34872 & \\
$2,1,2$ & 12,27474 & 12,38615 & \\
$2,1,3$ & 12,21471 & 12,34840 & \\
$3,1,1$ & 12,27813 & 12,39011 & \\
\hline
\end{tabular}

Source : Primary Data (2019)

The rice price on the wholesale level in Indonesia fluctuated each month but relatively increased each year. The most important thing from the fluctuated price, especially on the onion, potato, and rice commodity, was the hoarding behavior done by some producers. This type of producer would increase the product's price when the demand was increasing (Dargistan, Edgal, et al., 2017). This price fluctuation was not only affected the producer and consumer but also interfering with food security in a country (Gouel, 2013; Serra and Gil, 2013).

The level of rice consumption in Indonesia also depends on the demand and supply from the aspect of quality and price in the market. The cobweb theory explained that the amount of supply and demand could affect the price in the market setting (Naimzada, 2016). The supply and demand model is effective in describing the power of the market in determining the product price, the amount of product required to stock, and the number of goods and services needed by the consumer (Anokye., et al, 2014).

Based on the National Institute of Statistical Data (2019), the number of rice consumption/capita in each week and month was significantly decreasing. This happened due to some factors: using another staple food option, the decrease in rice consumption, and the increase of the rice price. The Cobweb theory already explained that supply and demand would be affected the price fluctuation, consequently the wholesale seller always using the amount of market demand and supply in determining the rice price in the following season.

\section{The Determination of ARIMA Model on the Rice Price on International Level}

Based on Table 8 the best ARIMA model is $(3,1,7)$ with the lowest accuracy value (AIC dan SC) of 8,690954 and 8,937300.

Table 8. ARIMA based on the Estimation Result

\begin{tabular}{cccc}
\hline Orde & AIC & SC & ARIMA Model \\
\hline $1,1,1$ & 9,963681 & 10,03019 & \\
$1,1,2$ & 9,753728 & 9,842405 & \\
$1,1,3$ & 9,755163 & 9,866008 & \\
$1,1,4$ & 9,701993 & 9,835007 & $3,1,7$ \\
$1,1,5$ & 9,700100 & 9,855284 & \\
$1,1,6$ & 9,673697 & 9,851050 & \\
$2,1,1$ & 9,675992 & 9,765118 & \\
& & &
\end{tabular}




\begin{tabular}{lll}
$2,1,2$ & 9,747064 & 9,858472 \\
$3,1,1$ & 9,124765 & 9,236741 \\
$3,1,2$ & 9,052724 & 9,187095 \\
$3,1,3$ & 9,056681 & 9,213447 \\
$3,1,4$ & 8,905544 & 9,084706 \\
$3,1,5$ & 8,919959 & 9,121515 \\
$3,1,6$ & 8,888236 & 9,112188 \\
$3,1,7$ & 8,690954 & 8,937300 \\
$3,1,8$ & 8,755470 & 9,024212 \\
\hline
\end{tabular}

Source : Primary Data (2019)

The international rice circulated in Indonesia was coming from Thailand. Based on the Rice Market Monitor (RMM) conducted by the Food and Agriculture Organization of the United Nations (FAO), Indonesia and Thailand was the largest producer of rice in 2017. Based on the Mundi Index, the rice price on the International level fluctuated in each month and year in U\$/Ton.

The need to export rice commodities also affected the price fluctuation. Based on the cobweb theory, the supply and demand model was the most effective model in describing the power of the market in determining the product price, the number of products required to be stocked, and the number of goods or services demanded (Anokye, et al,2014). The higher demand from other countries resulted in higher prices, which resulted in stable food commodities in the exporter country. The cobweb theory is very important in predicting the factors that affect the price fluctuation at certain times.

ISSER (2008) stated that a high food commodity price affects the countries and populations differently. The exporter country usually obtains benefits from international trade, while the importer country usually must be striving for their domestic food security. Most African countries are cereal importer which caused them must be striving for their food security due to the higher cereal's price. A high food commodity price also caused the impoverished community must be limiting food consumption or shifting to an unhealthy lifestyle that could be dangerous to their health. The market plays an important role in distributing the food community in or out of the country (Anokye, et al, 2014).

\section{Forecasting}

Forecasting was conducted after the best model of ARIMA chosen based on the lowest accuracy value. The paddy grain and rice price forecasting on some levels done to predict the price in the next 6 months (December 2018-May 2019 or the $132^{\text {nd }}-137^{\text {th }}$ month). The price used to predict the price was the actual price in January 2008 until 2018 (the $1^{\text {st- }} 131^{\text {st }}$ month).

\section{Paddy Grain Price Forecasting on the Farmer Level}

The rice forecasting on the wholesale level in the next six months (December 2018May 2019, the $\left.132^{\text {nd }}-137^{\text {th }}\right)$ was predicted according to the ARIMA model $(1,1,2)$ that shown in Figure 6. 


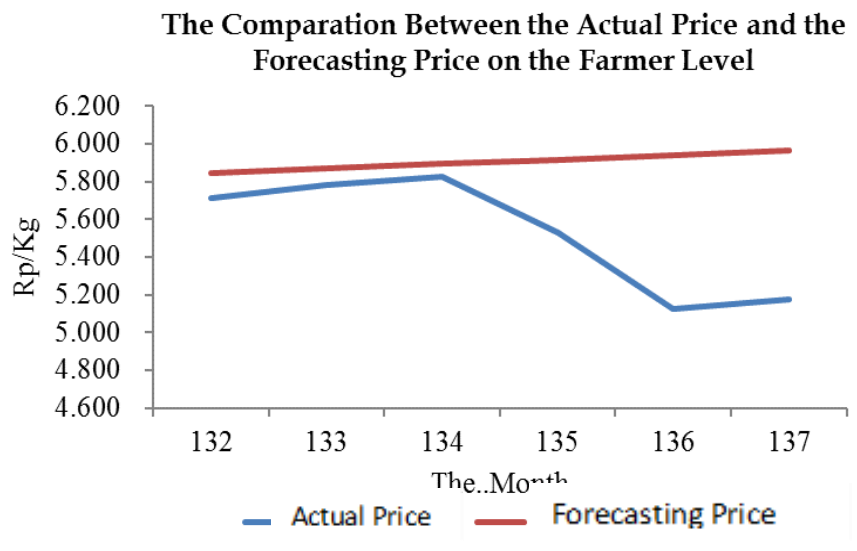

Figure 6. The Comparison Between the Actual Price and the Forecasting Price on the Farmer Level

Source : Processed Primary Data, 2019

Based on the graphic, the actual and forecasting price from December 2018 to May 2019 (the $136^{\text {th }}-137^{\text {th }}$ month) ranged above the IDR 5,000/kg. The forecasting paddy grain price always increases each month, while the actual price decreases in March until April 2019. The price decreases due to the harvesting period and the availability of the rice stock (National Institute of the Statistical Data, 2019). The paddy grain price reaches IDR 5,127/ kg in April 2019 or decreases by $7.65 \%$ and in May 2019 increases by $0.88 \%$ or as much as IDR $5,172 / \mathrm{kg}$.

\section{Paddy Grain Price Forecasting on the Milling Level}

The rice forecasting on the wholesale level in the next six months (December 2018-May 2019, the $\left.132^{\text {nd }}-137^{\text {th }}\right)$ was predicted according to the ARIMA model $(1,1,2)$ that shown in Figure 7.

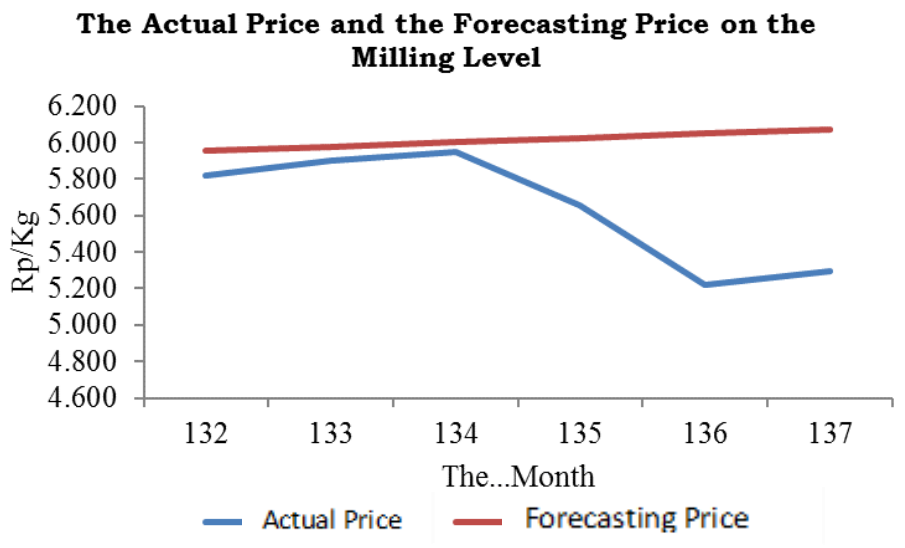

Figure 7. The Comparison between the Actual Price and the Forecasting Price on the Milling Level

Source : Processed Primary Data, 2019

Based on the graphic, the actual paddy grain price from December 2018 until May 2019 (the $132^{\text {nd }}-137^{\text {th }}$ ) ranged between the IDR 5,000/ kg and IDR 6,000/kg. The forecasting paddy grain price on the milling level was increasing each month, while the actual price was decreasing. This happens because of the decreasing price 
on the farmer level during the harvest period. According to the National Institute of Statistical Data, on the $136^{\text {th }}$ month (April 2019) the paddy grain price decreases by $7.65 \%$ or reaches IDR $5,221 / \mathrm{kg}$, and on the $137^{\text {th }}$ month (May 2019) the price increases by $1.47 \%$ or reaches IDR $5,298 / \mathrm{kg}$.

\section{Rice Price Forecasting on the Wholesale Level}

The rice forecasting on the wholesale level in the next six months (December 2018-May 2019, the 132nd-137th) was predicted according to the ARIMA model $(1,1,3)$ that shown in Figure 8.

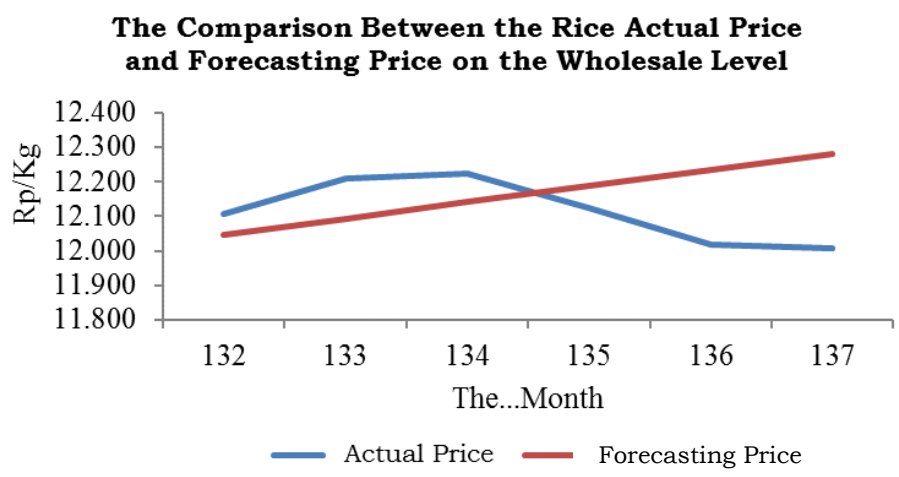

Figure 8. The Comparison Between the Rice Actual Price and Forecasting Price on the Wholesale Level

Sources : Processed Primary Data, 2019

Based on the graphic, the actual price and the forecasting price on the wholesale level are not differ significantly. The actual price was around IDR $12,000 / \mathrm{kg}$ on each month. Then the price decreases slowly because of the decreasing price of the paddy grain. The forecasting price rang around IDR $12,000 / \mathrm{kg}$ which is not significantly different from the actual price.

Based on the National Institute of Statistical Data (2019), the rice price of the international level on the $132^{\text {nd }}$ month (December 2018) reaches IDR $12,106 / \mathrm{kg}$ or increases by $2.26 \%$ in comparison to December last year. The rice price on the wholesale level on the $133^{\text {rd }}$ month (January 2019) increases by $0.87 \%$ or reaches IDR $12,211 / \mathrm{kg}$. The rice price on the $134^{\text {th }}$ month also increases by $0.27 \%$ because of the rice stock from the previous month still available. During the $135^{\text {th }}-136^{\text {th }}$ month (March-April 2019) the rice price decreases. This happens because of the harvest period increases the rice stock in the market.

\section{Rice Price Forecasting Price on the International Level}

The rice forecasting on the wholesale level in the next six months (December 2018-May 2019, the 132 ${ }^{\text {nd }}$ - $\left.137^{\text {th }}\right)$ was predicted according to the ARIMA model $(3,1,7)$ that shown in Figure 9. 
The Comparison Between Rice Actual Price

and Forecasting Price on the International Leve1

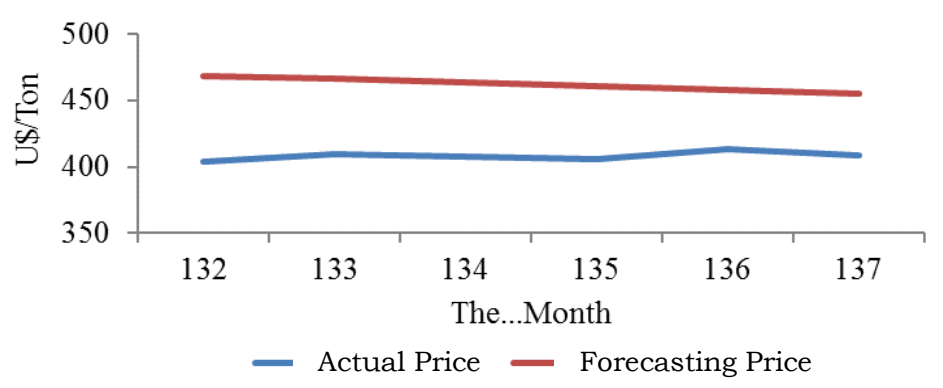

Figure 9. The Comparison Between Rice Actual Price and Forecasting Price on the International Level

Source : Primary Data, 2019

Based on the graphic, the actual price and the forecasting price on the international level are not significantly different. The rice actual price is around US\$ $400 /$ ton and relatively increases each month because of the international price of rice increases (especially in Thailand). The forecasting price also is obtained around US\$ 400/ton which is not significantly different from the actual price.

According to the Internasional Food and Agriculture Organizations (FAO), the lowest international export rice price (white rice variety $25 \%$ broken) from Thailand is around IDR $5,395 / \mathrm{kg}$ (on the Juni 2019), which is significantly different from the rice price on the national level (around IDR 12,000/kg). The Indonesia Paddy Grain and Rice Entrepreneurship stated that there were some factors affected the high price in Indonesia:

a. Production Factor

Rice production is conducted conventionally in which the size of agricultural land is small. The agricultural technological assumes to be ineffective and inefficient to use due to high operational costs so it contributes to the high domestic rice price.

b. Agricultural Land Rent

The rent cost of agricultural land is an issue that affects the high domestic rice price in Indonesia. According to the Institute for Development of Economics and Finance (INDEF), most farmers usually rent agricultural land with a wide less than 0.50 hectares. The high rent cost of the land contributes to the high rice price.

c. Laborer Fees

The number of agricultural laborers in Indonesia is still low, while the demand remains high, which causes the fees for the laborers is still high (ranged between IDR 50.000-70.000/days).

d. Transportation Charge

The high cost of transportation and inadequate transportation facilities also contributes to the high rice price in Indonesia. 


\section{CONCLUSION}

ARIMA Model is qualified to make a prediction using all patterns and autocorrelation in time-series data. This study shows and validates statistically that the error prediction in an ARIMA time series does not correlate and normally distributed with the mean of zero and consistent variance value. Therefore, the best ARIMA model for the paddy grain price on the farmer level is $(1,1,2)$, paddy grain price level on the milling level is $(1,1,2)$, rice price on the wholesale level is $(1,1,3)$, and the international price of rice is $(3,1,7)$.

\section{RECOMMENDATION}

The result showed that each data have a different model of ARIMA. ARIMA model has a limitation in the accuracy of the forecasting, but it could be used on a more extended time-series data prediction in the time progression. Morefurther, in forecasting, the data collection and the selection of the forecasting technique is required more specific considerations.

\section{REFERENCES}

Anokye, Martin., Francis T. Oduro, et al. 2014. Dynamics of Maize Price in Ghana: Linear versus Nonlinear Cobweb Models. Journal of Economics and Sustainable Development. 5(7): 8-13. Diakses dari https://www.iiste.org/Journals/index.php/JEDS/article/view/12557

Arısoy, Hasan \& Zeki Bayramoğlu. 2017. Determination of the Effect of Price Fluctuations on Producer Income - the Case of Potatoes. Turkish Journal of Agriculture - Food Science and Technology. 5(11): 1342-1349. Diakses dari http:/ / www.agrifoodscience.com/index.php/TURJAF/article/view/1356

Badan Pusat Statistik. 2016. https://www.bps.go.id/. Diakses pada tanggal 19 Desember 2018 pukul 22.00 WIB.

Brock W. A. \& Hommes C. H. 1997. A rational route to randomness. Econometrica, 65 (5):1059-1095. DOI: 10.2307/2171879 Diakses dari https://www.jstor.org/stable/2171879

Cetin I, Esengün K. 2013. Amasya Ilinde Yaygin Olarak Yetistirilen Urunlerde Verim ve Fiyat Riski. KMÜ Sosyal ve Ekonomïk Arastirmalar Dergisi. 15 (25): 57-65, Karaman. Diakses dari http://dergi.kmu.edu.tr/userfiles/file/aralik2013/5765.pdf

Dağıstan, Erdal., Tuğçe Kızıltuğ \& Ahmet Duran Çelik. 2017. Reasons for Seasonal Potato Price Fluctuations in Turkey. Asian Journal of Agricultural Extension, $\begin{array}{llll}\text { Economics } & \& & \text { Sociology. } & 18(3):\end{array}$ https:// doi.org/ 10.9734/AJAEES/2017/34647

Ezekiel, M. 2013. The Cobweb Theorem. The Quarterly Journal of Economics. Vol. 52, No. 2 (Feb., 1938), pp. 255-280, Oxford University Press, Diakses dari http://www.jstor.org/stable/ 1881734. 
Firdaus, M. 2011. Aplikasi Ekonometrika Untuk Data Panel dan Time Series. Edisi Revisi. PT Penerbit IPB Press: Bogor.

Gouel C. 2013. Optimal Food Price Stabilisation Policy. European Economic Review 57(2013)118-134.

Hadiansyah, F.N. 2017. Prediksi Harga Cabai dengan Pemodelan Time Series ARIMA. Journal on Computing. 2(1): 71-78.

IndexMundi.2018.https:// www.indexmundi.com/Commodities/?commodity=rice\&m onths=120. Diakses pada tanggal 10 Desember 2018 pukul 08.30 WIB.

ISSER, Institute of Statistic Social and Economic Research. 2008. State of the Ghanaian Economy University of Ghana-Legon.

Juanda, B. dan Junaidi. 2012. Ekonometrika Deret Waktu. PT Penerbit IPB Press: Bogor.

Makridakis Spyros, Wheel Wright Steven C, \& Victor E, McGee. 1999. Metode dan Aplikasi Peramalan. Edisi Ke-2. Jakarta: Erlangga.

Mariska, Mega. 2016. Analisis Pengaruh Kebijakan Harga Pembelian Pemerintah Terhadap Permintaan Beras di Kabupaten/Kota Provinsi Lampung Tahun 20092013. Skripsi. Fakultas Ekonomi dan Bisnis. Universitas Lampung.

Naimzada, Ahmad. and Nicolò Pecora. 2016. Memory, market stability, and attractors coexistence in a nonlinear cobweb model. Journal of Difference Equations and Application. ISSN: $1023-6198$ (Print) 1563-5120 (Online).

Novanda, R.R., Eko Sumartono, Putri S.Asriani, Ellys Yuliarti, Ketut Sukiyono., Basuki S.Priyono, Irnad, Reswita, Melly Suryanti, Vera Octavia. 2018. A Comparison of Various Forecasting Techniques for Coffee Prices. Journal of Physics: Conf. Series 1114 (2018) 012119.

Putri, Maria, C.K dan Wiwik Anggraeni. 2018. Penerapan Metode Campuran Autoregressive Integrated Moving Average dan Quantile Regression (ARIMA-QR) untuk Peramalan Harga Cabai Sebagai Komoditas Strategis Pertanian Indonesia. Jurnal Teknik ITS. 7(1): 132-137.

Salwa, Nany, Nidya Tatsara, Ridha Amalia, \& Aja Fatimah Zohra. 2018. Peramalan Harga Bitcoin Menggunakan Metode ARIMA (Autoregressive Integrated Moving Average). Journal of Data Analysis. 1(1): 21-31.

Sarkar A. 1992. On the Formation of Agricultural Prices. Journal of development economics 0304-3878/93/\$06.00 O 1993-Elsevier Science Publishers B.V. All rights reserved, 41 (1993) 1-17. North-Holland.

Sena, D. dan Nagwani N.K. 2015. Application of Time Series Based Prediction Model to Forecast Per Capita Disposable Income. IEEE International Advance Computing Conference (IACC): 454-457. DOI: 10.1109/IADCC.2015.7154749. 
Serra T, \& Gil J.M. 2013. Price Volatility in Food Markets: Can Stock Building Mitigate Price Fluctuations? European Review of Agricultural Economics. 40 (3): 507-528. https://doi.org/10.1093/erae/jbs041

Sugiarto, S., Bustami, Rustam E. 2017. Penduga Model Arima Untuk Peramalan Harga Tbs Kelapa Sawit Di Propinsi Riau. Jurnal Sains, Teknologi dan Industri. 15(1): $35-40$.

Sukiyono, K., Musriyadi Nabiu, Bambang Sumatri, R.R. Novanda, Nyayu N. Arianti, Sriyoto, M. M. Zulkarnain Yuliarso, Redy Badrudin, M. Mustopa Romdhon, H. Mustamam. 2018. Selecting an Accurate Cacao Price Forecasting Model. Journal of Physics: Conf. Series 1114 (2018) 01211.

Sukiyono, Ketut dan Rosdiana. 2018. Pendugaan Model Peramalan Harga Beras Pada Tingkat Grosir. Jurnal Agrisep. 17.1.23-30.

Web Definition, (2014). Cobweb Model. http://en.wikipedia.org/wiki/Cobweb model. assessed 11 th February, 2014.

Wei, W. W. S. 2006. Time Series Analysis.Addison Wesley: New York.

White, B. \& Dawson, P. J. 2005. Measuring Price Risk on UK Arable Farms. Journalof Agricultural Economics, 56 (2), 239-252 